\title{
OPPORTUNITY TO USE CITY PROSPERITY INDEX FOR INDONESIAN MUNICIPAL DEVELOPMENT PLANNING PROCESS
}

\author{
I Nyoman Suluh WIJAYA
}

DOI: $10.21163 / G T \_2019.141 .24$

\begin{abstract}
:
This paper argues the incompatibility of methodological prosperity approach toward the practical planning administrative circumstance of Indonesian municipalities. Regarding the urban sustainability, integrated planning analysis is required to define the specific goals. For the above circumstance, UN Habitat suggests more people-centred prosperity that leads to more holistic approach to integrating productivity, infrastructure, quality of life, equity and social inclusion, and environmental sustainability into a coherent framework of planning analysis. However, some argumentations are still existed toward the incompatibility in response to the common instable planning administration in Indonesia. This paper uses the resulted value of CPI calculation upon Malang City that was demonstrated in 2017 Habitat CPI Courses. Further, the calculation result is analysis toward the practical circumstances of Malang City. This paper reveals two important points that are: i) some difficulties is pictured on the stage of problem and goals definition by unavailable detailed picture of relation among the productivity, infrastructure, quality of life, equity and social inclusion, and environmental sustainability in analysis; ii) there is wide uncertainty toward indicator value due to the lack good data for the analysis.
\end{abstract}

Key-words: City Prosperity Index (CPI), Data, Indicators, Methodological Framework.

\section{INTRODUCTION}

Measuring development in term of Quality of Life (QoL) could be stressful work for city government due to the complicated framework. Since development is considered in more social-political tendency, more comprehensive methodological framework is required rather than the economy-based aspects (Discolli et al., 2014; Findlay, Rogerson, and Morris 1989; Marans, 2012). Meanwhile, for many city governments, the comprehensiveness means struggle with uncertain political and decision-making situation (Holmberg, Rothstein, and Nasiritousi, 2009).

Recently, global economical crises makes cities are more considered as the key driver of QoL improvement (Wong, 2015). City in its creativity in developing the economics development is unique approach to maintain the sustainability (Turon \& Gomis, 2016). Additionally, measuring city development becomes more important rather than globally conducted on country level. United Nation Human Settlement Programme (UN-Habitat), addressing the required integration between economy and social aspects, introduces the City Prosperity Index (CPI) since 2012 (UN-HABITAT, 2013; Bonaiuto et al, 2015). CPI is proposed as the testing tool that eliminates the gap between the stakeholders of development (UN-HABITAT, 2013). It is developed based on incremental approach of productivity, QoL, infrastructure, equity and social inclusion, and environmental sustainability (UN-HABITAT, 2013).

\footnotetext{
1 University of Brawijaya, Department of Urban And Regional Planning, Malang, Indonesia, nyoman@ub.ac.id
} 
Further, these five are existed as the five-dimension prosperity wheel of CPI (Bonaiuto \& Alves, 2012). For the practical operation, CPI consists with large numbers of indicators derived from each dimension. Then, large numbers of information is required for the analysis in order to state the exact circumstance of each dimension. In strategic planning view, exact circumstance of each dimension leads exact definition of planning problem and goal of the plan. Indeed, interrelation among the dimension should be defined clearly.

Unfortunately, unavailable excellent information is a common problem of development planning administration in many developing countries In case of development planning system, problem of severe information circumstances is also seriously occurred in Indonesia (Wijaya et al., 2012). In this situation, the practical development may not be accurately measured by the difficulties in defining the problem and the plan's goal. Moreover, disintegration among elements, stakeholders, and other development resources are difficult to manage. In this mess-situation of planning administration, CPI may not adequately improve planning and the development result.

Therefore, this paper tries to describe the possible constraint of CPI operation toward Indonesian municipal development planning system. Here, demonstration of CPI operation for Malang City as a sample case of Indonesian big city is analyzed. By the demonstration, some administration weakness is identified in order to propose further improvement of CPI in Indonesia.

\section{CPI AND THE RECENT PRACTICE IN INDONESIAN CITY DEVELOPMENT AND PLANNING}

Various study on measuring countries development considered the weakness of economic indicator and the measurement. GDP may not be the best indicator for the successful development. Separately, non-economy based indicators are used socially and politically to define the successfulness of the development (Discolli et al., 2014; Findlay et al., 2012). Addressing to the comprehensive measurement, some discussions try to integrate economy and social dimension of the development.

\subsection{UN-Habitat's City Prosperity Index}

Various studies try to define the integration between economy and social dimension of the development, especially in a country scale (Wills-Herrera et al., 2009). Concerning to the city/municipality scale, the integrated measurement tool is insufficiently formulated. In more practical way, municipal scale measurement requires more specific indicator that should be derived from each economy and social dimension of the development.

Since the trend of urban quality issue becomes the focus of global development discussion, the demand of municipal scale measurement tools also become high. Here, concept of urban neighborhood development as the key of global development became increasingly popular (Bonaiuto \& Alves, 2012). Here, relevant stakeholder's interactions are more specifically depicted in order to get more objective people-centred prosperity valuation. More precisely, the City Prosperity Index proposed by UN Habitat in 2012 in order to bridge the integration and accommodate the stakeholder better (UN-HABITAT, 2013). Furthermore, CPI is also proposing a global, multidimensional tool to test prosperity in cities (UN-HABITAT, 2013). 
The conception of the CPI comes with the theme of urbanized world. In the situation where more people are inhabited in urban area, CPI concept is designed in term of a new type of city "that is a "good", people-centred city, that is capable of integrating the intangible and tangible facets of prosperity and the process shedding off the inefficient, unsustainable forms of functionalities of the city' (UN-HABITAT, 2013). It leads to the move from national income indicators to the people centred prosperity.

In the practical operation, CPI consists of both an analytical and an action-planning tool (strategically form). CPI gives opportunity for urban managers to monitor the performance of urban management, especially in strategic policy making and the assessment. More important, CPI gives opportunity to investigate the impact of development policy on the overall QoL of the city. CPI also becomes an effective tool of municipal action planning in strategically form. It enables municipal government to accurately define their problem areas, weakness, and constraint that are preventing city to actualize prosperity. It provides a set of indicators. It also requires knowledge and information to analyze the circumstance and design the effective plan to resolve problems identified and numerically visualized through each indicator calculation.

Methodologically, 'prosperity wheel of CPI' are consist with five basic dimensions that are: productivity, infrastructure, quality of life, equity, and environmental sustainability (UN-HABITAT, 2013). Incrementally productivity and quality of life have been inspired by the Human Development Index view. Meanwhile, infrastructure, equity, and environmental sustainability have been utilized in order to accommodate the other dimension of prosperity. Further, the indicators are required for each dimension as the best diagnostic tool to state the dimension exactly. For these indicators, CPI still gives opportunity to the development of new indexes for the comprehensiveness (Bonaiuto \& Alves, 2012).

Prosperity Wheel of CPI depicts the interrelation among the dimensions. The dimensions are interrelated. The relation leads to the interdependencies among them. Therefore, CPI analysis results a key problem from the resulted interrelation among the dimension. It may be both positive and negative (enhancing services enhances equity; enhancing productivity may, in some cases, diminish environmental sustainability). Therefore, CPI becomes an effective tool to address more than just economic growth for urban development.

Table 1. Prosperity index and the variables taken from UN-Habitat 2012.

\begin{tabular}{|l|l|}
\hline Productivity Index & $\begin{array}{l}\text { Total output of goods and services (value added) } \\
\text { produced by a city's population during a specific year by } \\
\text { including variables such as capital investment, } \\
\text { formal/informal employment, inflation, trade, savings, } \\
\text { export/import and household income/ consumption }\end{array}$ \\
\hline Quality of Life Index & $\begin{array}{l}\text { It is a combination of three sub-indices: education, } \\
\text { health and public space }\end{array}$ \\
\hline $\begin{array}{l}\text { Infrastructure development } \\
\text { Index }\end{array}$ & $\begin{array}{l}\text { It combines two sub-indices: infrastructure proper and } \\
\text { housing }\end{array}$ \\
\hline $\begin{array}{l}\text { Equity and Social Inclusion } \\
\text { Index }\end{array}$ & $\begin{array}{l}\text { It has three sub-indexes: air quality (PM10), } \mathrm{CO}_{2} \\
\text { emissions and indoor pollution }\end{array}$ \\
\hline $\begin{array}{l}\text { Environmental sustainability } \\
\text { index }\end{array}$ & $\begin{array}{l}\text { It combines measures of inequality of income/ } \\
\text { consumption (Gini coefficient) and inequality of access } \\
\text { to services and infrastructure }\end{array}$ \\
\hline
\end{tabular}




\subsection{Index and Indicators of Prosperity}

As written above, CPI indicates the various connection and interdependencies among the dimensions of prosperity. Here, each dimension is derived into more detail and specific indicators. Correspond to the dynamic social dimension circumstance; CPI could be considered draft that gives a starting point for the improvements and refinements (UNHABITAT, 2013). In this case, for each dimension, the operator of CPI may develop the specific and certain indicator. They may be different from one country to the other. Basic dimension and indicators of each prosperity dimension are listed in Table 1. Here, index in the term of prosperity also are known as dimensions. In practical application of CPI, variables of each dimension (indicators) are open in nature. Thus, each CPI operator (analyzer) may derive much specific indicators.

Each dimension is connected to the others in order to define the prosperity (UNHABITAT, 2013). It means that each dimension's value gives impact to the other dimension. Therefore, the key problem can be identified among the dimension through the interrelation system. In strategic planning, the key problem should be firstly treated for the comprehensively prosperity improvement. This system is described as prosperity wheel of CPI (Bonaiuto \& Alves, 2012).

\subsection{Indonesian Municipal Planning Administration}

So far, Indonesian development system combines bottom-up and top-down planning in conducting the decentralization. Development plan is hierarchically planned and implemented from central to municipal government. For each level (national, province, municipality) there are long-term plan, short-term plan, those are detailed into each sector plan. The long-argued circumstance of Indonesian development planning system is the incapability of the planners in defining the problem of development. In many cases, the problem is ambiguous. So that, the resulted plan means nothing in improving urban and people situation, especially in term of QoL, Environmental Sustainability rather than infrastructure development. Problem definition in planning and decision-making is surely driven by the availability of excellent information (data). Many argue that Indonesian government, especially in municipal level, has serious weakness regarding the administration of the data/information. Lack of capability in compiling and managing the data are two poor Indonesian planning administrations. Otherwise, data are scattered in many stakeholders, many sectors. It makes the data identification is difficult to conducted. Moreover, the analysis become unreliable and mess in utilization.

\subsection{Malang Municipality and the Problem of Development}

Malang City is located in East Java Province, Indonesia. Malang is second big city in East Java named after Surabaya, the capital city. The 2016 census recorded 887443 people lives in the city. Malang has a total area of $145.28 \mathrm{~km}^{2}$. Administratively, Malang City area is divided into five districts. Generally, almost whole area of Malang City has been a built area for settlement, services, and other urban activities. Fig. 1 shows the planned land use and development by 2016. As seen in Fig. 1, recent crucial problem of Malang City is population growth, housing, and uncontrolled land use development. These problems are come along with never-ended poverty escalation and degradation of environment.

One municipal government innovation of development is urban settlement upgrading. This program is started in 2012 with various projects, especially targeted on high density 
settlement in urban area (hereafter: kampongs) and other urban area with slums tendency. In term of infrastructure development, this development innovation significantly improves the physical condition of the kampongs. This program is focusing on goal achieving of 100 $\%$ sanitation, $0 \%$ slums, and 100\% water supply. Totally, there are 60 kampongs have developed with specific themes, such as green kampong, art kampong, etc. However, other problems are appeared as the result of uncertain definition of kampongs. Some of the kampongs are currently identified as improper settlement due to the legality, vulnerability to flood, land slide, etc. Further, the infrastructure development is still uncertain to improve the QoL of the people.

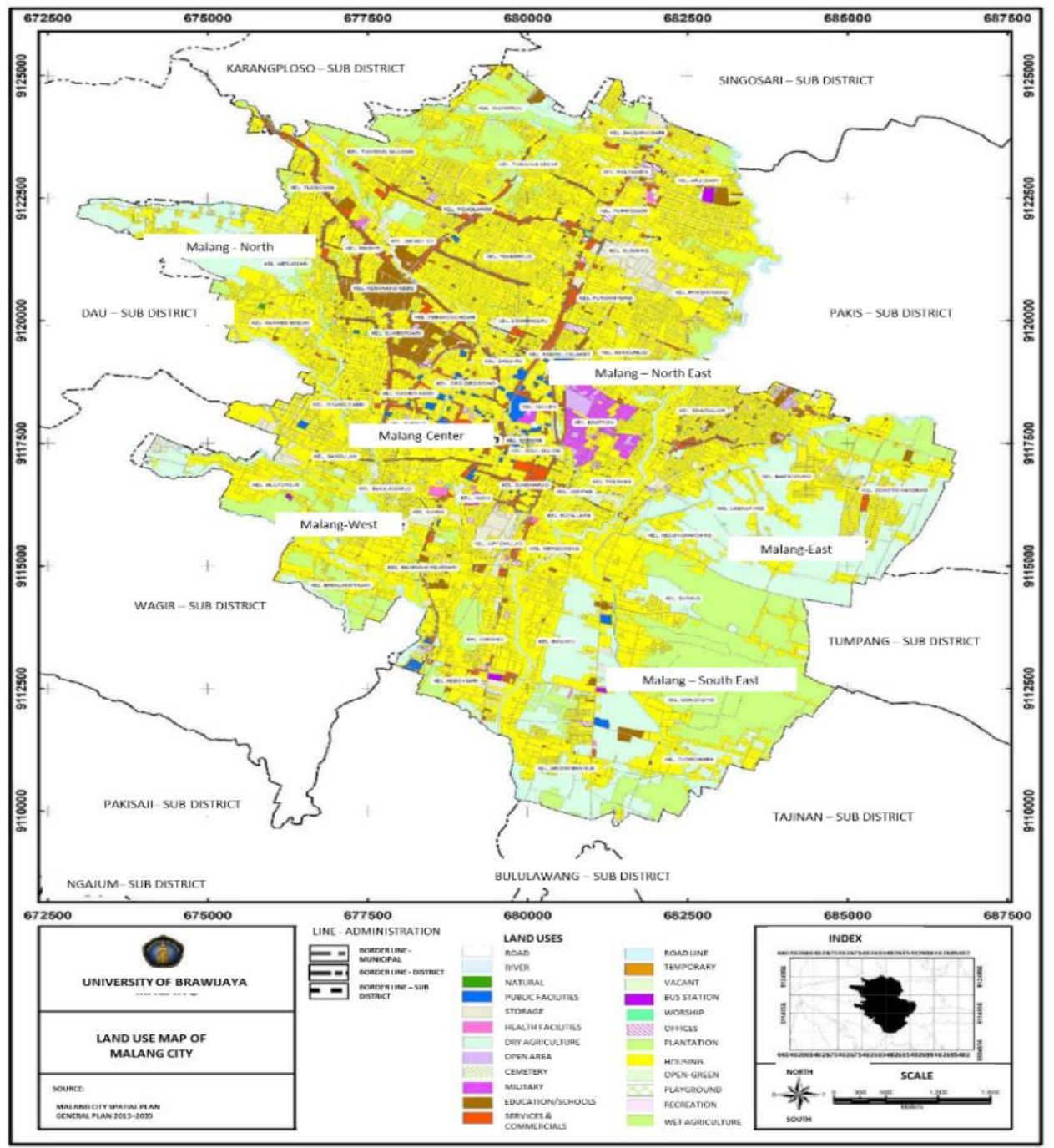

Fig. 1. Land use and development area of Malang City. 


\section{RESEARCH METHODOLOGY}

This research utilizes Malang City as the area for demonstrating the practical operation of CPI in helping problem definition of development plan. The CPI calculation technique has been already develop by UN-Habitat and utilized by this research for the demonstration. It is conducted based upon the existed data/information of each dimension of prosperity of Malang City.

All data/information are compiled by using Statistical Data of Malang City. It is compiled within the period of 2010 to 2016. Assessment toward the each indicator results the quality of each indicator by comparing to the targeted Global prosperity of Indonesia (assumed before by the UN-Habitat data 2015-2016).

\section{DATA ANALYSIS}

Based upon basic dimension and indicator of prosperity in Table 1, this research develops more detail sub dimension and other composed indicators. Here, Table 2 shows the developed indicator for each dimension. In Table 2, one social-political dimension is added in order to accommodate the administration circumstances of the development. This additional dimension is 'government and participation'.

Principally, each indicator is identified based upon the series data of Statistical Data of Malang City started from 2010 until 2016 (Malang City Central Bureau of Statistics, 2016). However, some important indicators couldn't be found in the documents. The calculation over transport network and intersection density is based upon the existing data of road and transportation development plan (Malang Municipal Planning Board, 2010). Meanwhile, regarding the share of renewable energy consumption, East Java Province statistical data of Energy and Mineral Resources 2016 shows no massive utilization of renewable energy in East Java, especially for Malang City (ESDM, 2016). Other basic data, such as population and demographical changes, the Statistical Data of Malang City 2010 to 2016 publishes the information with insignificant growth. However, these data are used for the calculation because it is the only formal data available.

Based upon the all data analysis, key problem of Malang City is identified. It is serious circumstance of environment sustainability. In practical word, main prosperity problem of Malang City is degradation of environment quality. Fig. 2 translates the value to the resulted graphic of analysis. Other interesting result is productivity value. It is in contrast to the high QoL, infrastructure development and urban governance. It shows that good QoL and infrastructure development are not in line with productivity. This situation gives impact to the conclusion that the influential interrelation cannot be exactly defined among city productivity, QoL, infrastructure development, and urban governance. Meanwhile, many researchers have ensured the mutual relation (Li \& Liu, 2018; Sun \& Cui, 2018).

Here, the accuracy of statistical data may come as the cause of the gap. Practically, the calculation is relied on less updated demography data that gives opportunity to calculation bias. Regarding indicator of city product per income, the Statistical Data of Malang City 2010 to 2016 only accounts formal economy activities or permitted business. Meanwhile, the informal activities grow significantly in the recent years. Other is low value of environmental sustainability compare to QoL and Equity and Social Inclusion.

Here, Statistical Data of Malang City 2010 to 2016 and East Java Province statistic data of Energy and Mineral Resources 2016 provides inadequate information for people 
fresh-water management, water pollution, and alternative energy development (Malang City Central Bureau of Statistics, 2016; ESDM 2016).

This circumstance makes the value of share renewable energy indicator low in the calculation. Then, the value of Environmental Sustainability also becomes low (Fig. 3).

Table 2. Developed Dimension-sub-dimension and the Indicators taken from UN-Habitat 2014.

\begin{tabular}{|c|c|c|}
\hline Dimension & Sub Dimension & Indicators \\
\hline \multirow[t]{3}{*}{ Productivity } & \multirow{2}{*}{ Economic Strength } & City Product capita $^{-1}$ \\
\hline & & Old Age dependency ratio \\
\hline & Employment & Unemployment Rate \\
\hline \multirow{10}{*}{$\begin{array}{l}\text { Infrastructure } \\
\text { Development }\end{array}$} & \multirow[t]{2}{*}{ Housing Infrastructure } & Improved Shelter \\
\hline & & Access to improved water \\
\hline & Social Infrastructure & Physician Density \\
\hline & ICT & Internet Access \\
\hline & \multirow[t]{3}{*}{ Urban Mobility } & Use of Public transport \\
\hline & & Length of transport network \\
\hline & & Traffic fatalities \\
\hline & \multirow[t]{3}{*}{ Urban form } & Intersection Density \\
\hline & & Street Density \\
\hline & & Land Allocated to street \\
\hline \multirow[t]{6}{*}{ Quality of life } & \multirow[t]{2}{*}{ Health } & Life Expectancy at Birth \\
\hline & & Under Five Mortality rate \\
\hline & \multirow[t]{2}{*}{ Education } & Literacy Rate \\
\hline & & Mean years of schooling \\
\hline & Security & Homicide rate \\
\hline & Public Space & Green Area per capita \\
\hline \multirow{4}{*}{$\begin{array}{l}\text { Equity and Social } \\
\text { Inclusion }\end{array}$} & \multirow[t]{2}{*}{ Economy Equity } & Gini Coefficient \\
\hline & & Poverty Rate \\
\hline & \multirow[t]{2}{*}{ Social Inclusion } & Slums Household \\
\hline & & Youth unemployment \\
\hline \multirow{5}{*}{$\begin{array}{l}\text { Environmental } \\
\text { Sustainability }\end{array}$} & \multirow[t]{2}{*}{ Air Quality } & PM 2.5 Concentration \\
\hline & & $\mathrm{CO}_{2}$ Emission \\
\hline & \multirow[t]{2}{*}{ Waste Management } & Solid collection \\
\hline & & Waste water treatment \\
\hline & Water and Energy & $\begin{array}{l}\text { Share of renewable energy } \\
\text { consumption }\end{array}$ \\
\hline \multirow[t]{3}{*}{$\begin{array}{c}\text { Urban Governance } \\
\text { and Legis-lation }\end{array}$} & $\begin{array}{l}\text { Participation and } \\
\text { Accountability }\end{array}$ & Voter turnout \\
\hline & \multirow[t]{2}{*}{ Municipal finance } & Own revenue collection \\
\hline & & Days to start a business \\
\hline
\end{tabular}


City Prosperity Index

(year 2016)

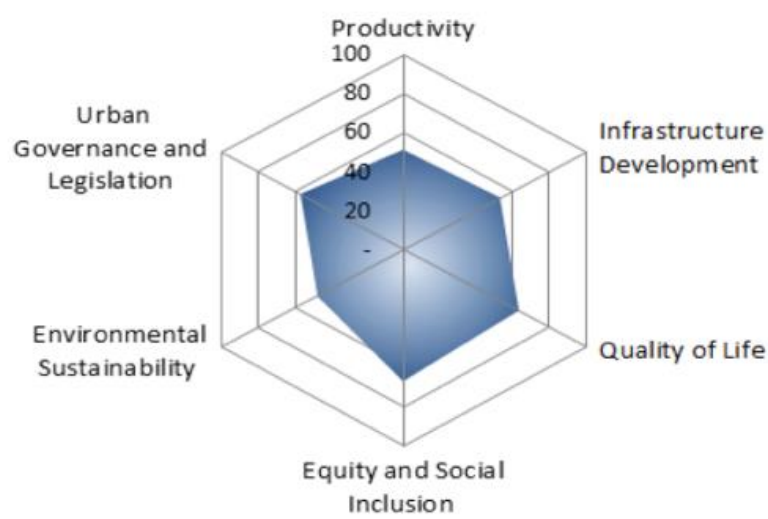

Fig. 2. Translated value of each CPI dimension into CPI radial graph.

This situation gives a picture that there seems no connection from the development of QoL and Equity-Social Inclusion to the Environmental Sustainability. On the contrary, many UN-Habitat case studies show QoL is in line with the Social Inclusion by the people empowerment in urban environment and settlement improvement programs. Further about the analysis on environmental sustainability, Fig. 3 is the resulted calculation graphic of the sub-dimension. This figure shows that Malang City has lack of water quality and also energy supply. These results become uncertain comparing to the development of infrastructure that is done by improving the situation of water and energy supply and also waste management.

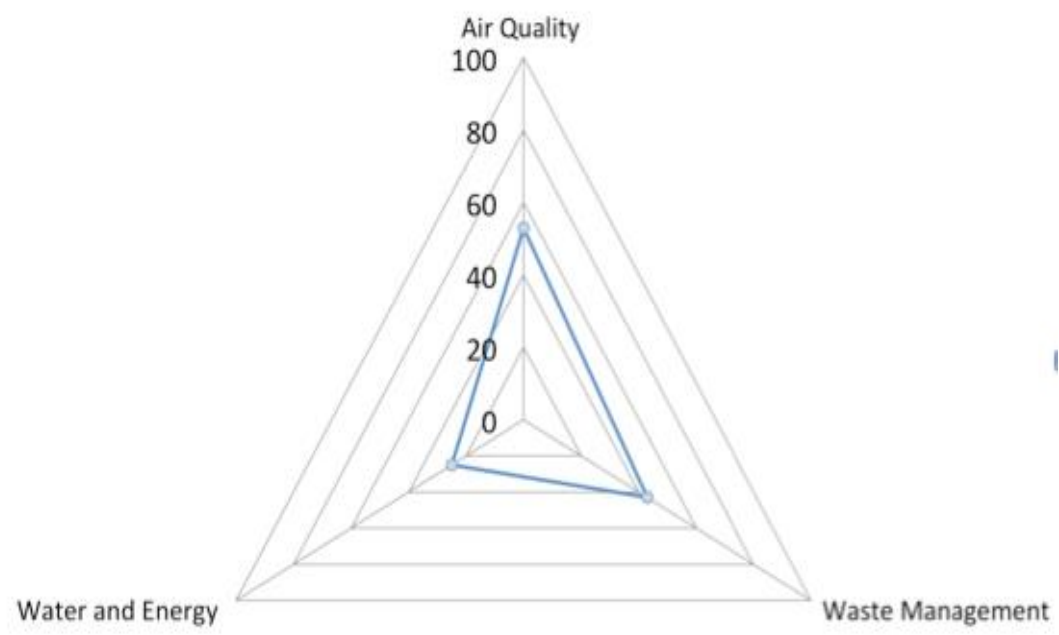

Fig. 3. Resulted calculation graphic of environmental sustainability sub-dimension. 


\section{CONCLUSION AND FUTURE WORK}

Based upon Malang City case, there is crucial obstacle to use CPI calculation for Indonesian municipal planning process. Reliable basic data/information for the calculation is not inadequately available. In case of Malang City, various data is in ill circumstance. The practical problem is not merely statistical survey methodology. The administration of data by the government is the key problem. By the demonstration of CPI calculation for Malang City, the insufficient qualified data/information about each indicator causes gap of calculation. Here, advance technical knowledge and sensitivity of the planner and the municipal government toward the data is highly required to assure the accuracy of data/information selection. Potential future work should be done to improve the CPI operation in Indonesian municipalities are:

- Defining the relation between the dimension in term of Indonesian development and planning system

- Assuring the suitable indicator should be derived from each dimension and sub dimension. Indeed, the administration of planning system becomes the field of consideration.

\section{REFERENCES}

Discoli, C., Martini, I., San Juan, G., Barbero, D., Dicroce, L., Ferreyro, C. \& Esparza, J. (2014) Methodology aimed at evaluating urban life quality levels. Sustainable Cities and Society, 10, $140-148$.

Findlay, A., Rogerson, R., and Morris, A. (1989), in what sense 'indicators' of quality of life? Built Environment, 14 (2), 96-106.

Marans, R, W. (2012) Urban Life Studies: An overview and implications for environment-behaviour research. Procedia - Social and Behavioral Sciences, 35, 9-22.

Holmberg, S., Rothstein, B., and Nasiritousi, N. (2009) Quality of government: what you get, Annual Review of Political Science, 12, 135-161.

Wong, C. (2015) A framework for 'city prosperity index': linking indicators, analysis and policy, Habitat International, 45(1): 3-9.

Turon, C. \& Gomis, J. (2016) Implementation of elements of sustainability applied to the urbanization of productive areas. Geographia Technica 11(2): 113-124.

UN-HABITAT (2013) State of the world's cities 2012/2013: prosperity of cities, UN-HABITAT, Retrieved from https://sustainabledevelopment.un.org/content/documents/745habitat.pdf [Accessed 12 March 2019]

Bonaiuto, M., Fornara, F.Ariccio, S., Cancellieri, U. G., and Rahimi, L. (2015) Perceived residential environment quality indicators (preqi's) relevance for un-habitat city prosperity index (CPI). Habitat International, 45, 53-63.

Bonaiuto, M. and Alves, S. (2012) Residential places and neighbourhoods: toward healthy life, social integration, and reputable residence, In Clayton, S. D. (Eds), The Oxford Handbook of Environmental and Conservation Psychology. Oxford University Press, New York. pp. 221-224.

Wijaya, I N. S, Yoshitake, T., and Deguchi, C. (2012) Differences between government officers' and academic experts' perspectives for improving public involvement in land use assessment in Indonesian municipalities. European Journal of Social Science, 27(2): 266-282. 
Wills-Herrera, E., Islam, G., and Hamilton, M. (2009), Subjective well-being in cities: a multidimensional concept of individual, social and cultural variables, Applied Research Quality Life, 4(2): 201-221.

Malang City Central Bureau of Statistics (2016) Malang City in Numbers 2010-2016. Retrieved from https://malangkota.bps.go.id/publication.html, [Accessed 13 March 2019]

Municipal Planning Board of Malang Municipality (2010) Municipal regulation of Malang city No. 4/2011 for spatial management of Malang City 2010 - 2030. Retrieved from http://sipr.malangkota.go.id/rtrw, [Accessed 14 March 2019]

ESDM Jatim (2016) Energy and mineral resources - East Java Province in numbers 2016, ESDM Jatim. Retrieved from http://esdm.jatimprov.go.id/esdm/index.php/esdm-angka-baru [Accessed 14 March 2019]

Sun, Y. and Cui, Y. (2018) Analyzing Urban infrastructure economic benefit using an integrated approach, Cities, 79, 124-133.

Li, Y. \& Liu, X. (2018) How did urban polycentricity and dispersion affect economic productivity: a case study of 306 Chinese cities. Landscape and Urban Planning, 173, 51-59. 